\title{
Lymphoblastic transformation of myelodysplastic syndrome
}

\author{
Hematology and Hemotherapy Center, Department of Internal Medicine, Department of Pathology.
}

Faculty of Medicine, State University of Campinas - Campinas, Brazil

\begin{abstract}
Mielodysplastic syndromes (MDS) are clonal disorders of the hemopoietic stem cell. About one third of the cases terminate in an acute leukemia, usually acute myeloblastic leukemia. However, few cases of transformation into acute lymphoblastic leukemia (ALL) have been described. We present a case of refractory anemia that transformed into ALL two months after diagnosis and was successfully treated with conventional chemotherapy. Two years later a hyperfibrotic form of MDS was detected in the patient, that soon after terminated in acute megakaryoblastic leukemia. The course of MDS in the present case provides evidence that MDS can involve a pluripotent stem cell, presenting clonal evolution, documented by successive changes in its clinical and hematological features.
\end{abstract}

UNITERMS: Myelodysplastic syndrome. Acute lymphoblastic leukemia. Clonal evolution. ,

\section{INTRODUCTION}

$\mathrm{T}$ he myelodysplastic syndrome (MDS) comprises a heterogeneous group of disorders of the hemopoietic stem cell presenting cytopenias in peripheral blood and cellular bone marrow with cell atypias. About $30 \%$ of the MDS develop acute leukemia, usually acute myeloblastic leukemia.' However, a small number of cases can transform into acute lymphoblastic leukemia ${ }^{2-12}$ or bilineal or biphenotypic leukemia, ${ }^{13-19}$ suggesting that the origin of this disorder may be at the level of a common progenitor cell that gives rise to hemopoietic as well as lymphoid cells. . $^{5,9,16,18,20-25} \mathrm{We}$ describe a case of MDS that presented a transformation into acute lymphoblastic leukemia two months after

Address for correspondence:

Cármino Antonio de Souza

Hematology-Hemotherapy Center

State University of Campinas - UNICAMP

Campinas/ SP - Brasil - C.P.6198 - CEP 13081-970 diagnosis. The patient was treated with polychemotherapy, achieving complete remission and normal bone marrow. Two years later she experienced a recurrence of MDS, that had different features than at initial diagnosis. She developed a new leukemic transformation with characteristics of acute megakaryoblastic leukemia. The course of MDS in this patient favours the hypothesis that the origin of the disorder in this case was at the level of a very early stem cell, developing clonal evolution with pronounced changes in disease pattern and type of leukemic transformation.

\section{CASE REPORT}

A 62 year-old white female was seen at the University Hospital, having presented weakness for two months. Moderate pallor and discrete splenomegaly were the only abnormalities found at physical examination. At this time, 
the leucocyte count was $2,2 \times 10^{9} / \mathrm{L}$ with $39 \%$ neutrophils, $56 \%$ lymphocytes, and 5\% monocytes. Hemoglobin concentration was $8,4 \mathrm{~g} / \mathrm{dL}$ with an MCV of $97 \mathrm{fl}$ and the platelet count was $330,0 \times 10^{9} / \mathrm{L}$. Bone marrow aspirate and biopsy were hypercellular with a decrease of the myeloid-erytroid ratio. Blast cell count was $4 \%$ of nonerithroid cells. Dysplastic features were present in erithroblastic, granulocytic and megakaryoblastic series. There was a slight increase in reticulin fibres (Fig. 1). These bone marrow findings were consistent with the diagnosis of myelodysplastic syndrome, refractory anemia type, according to the criteria established by the FAB Cooperative Group. ${ }^{26}$ Two months later, pallor and splenomegaly got worse. The leucocyte count was $0,8 \mathrm{x}$ $10 \% / \mathrm{L}$ with $10 \%$ neutrophils, $60 \%$ lymphocytes and $30 \%$
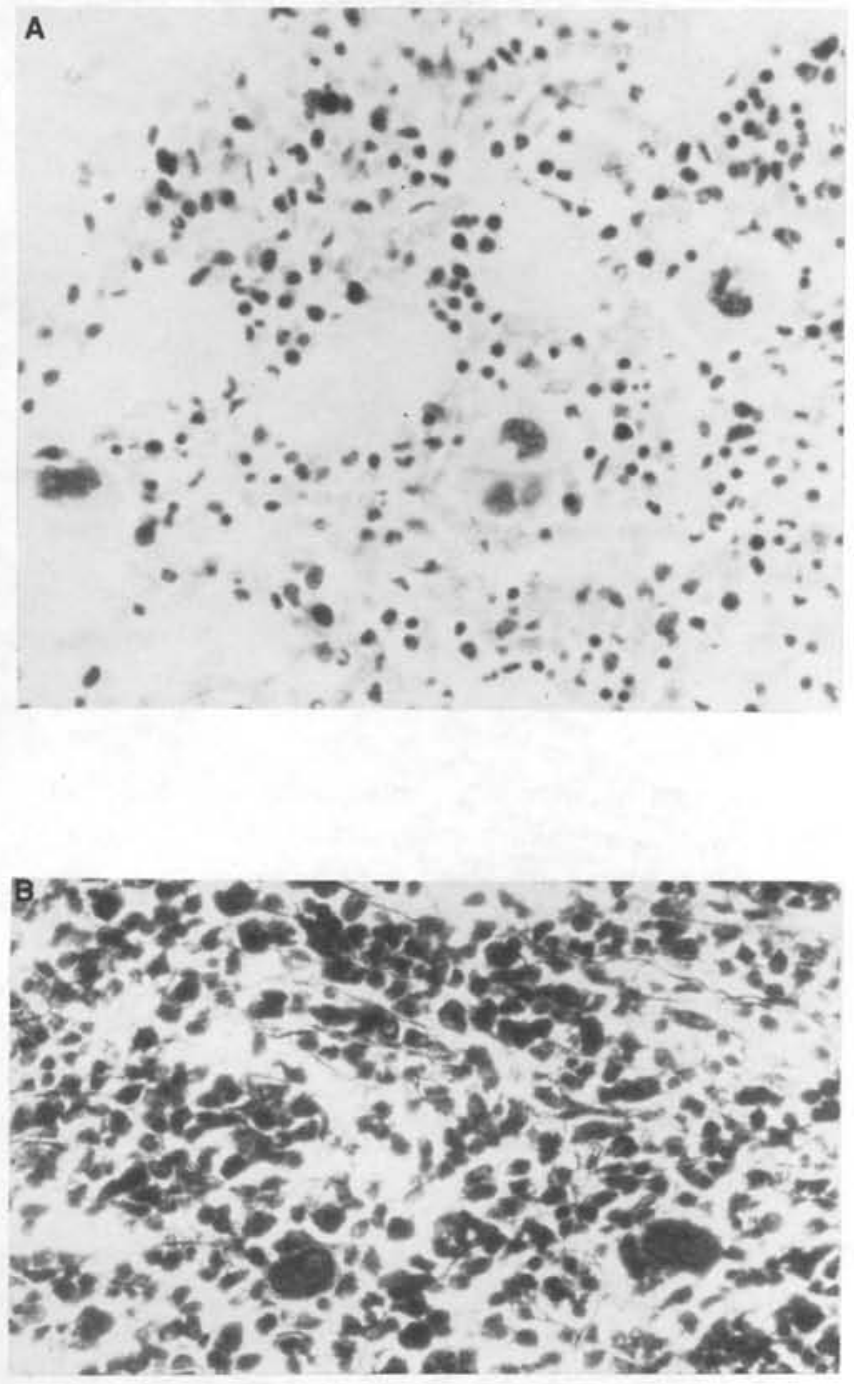

Figure 1 - Bone marrow biopsy at diagnosis of MDS. AHematopoietic tissue was hypercellular with atypical elements in all three cell lines, especially in megakaryocytes (H.E., 600x). BReticulin fibres were slightly increased (Gomori , 600x)

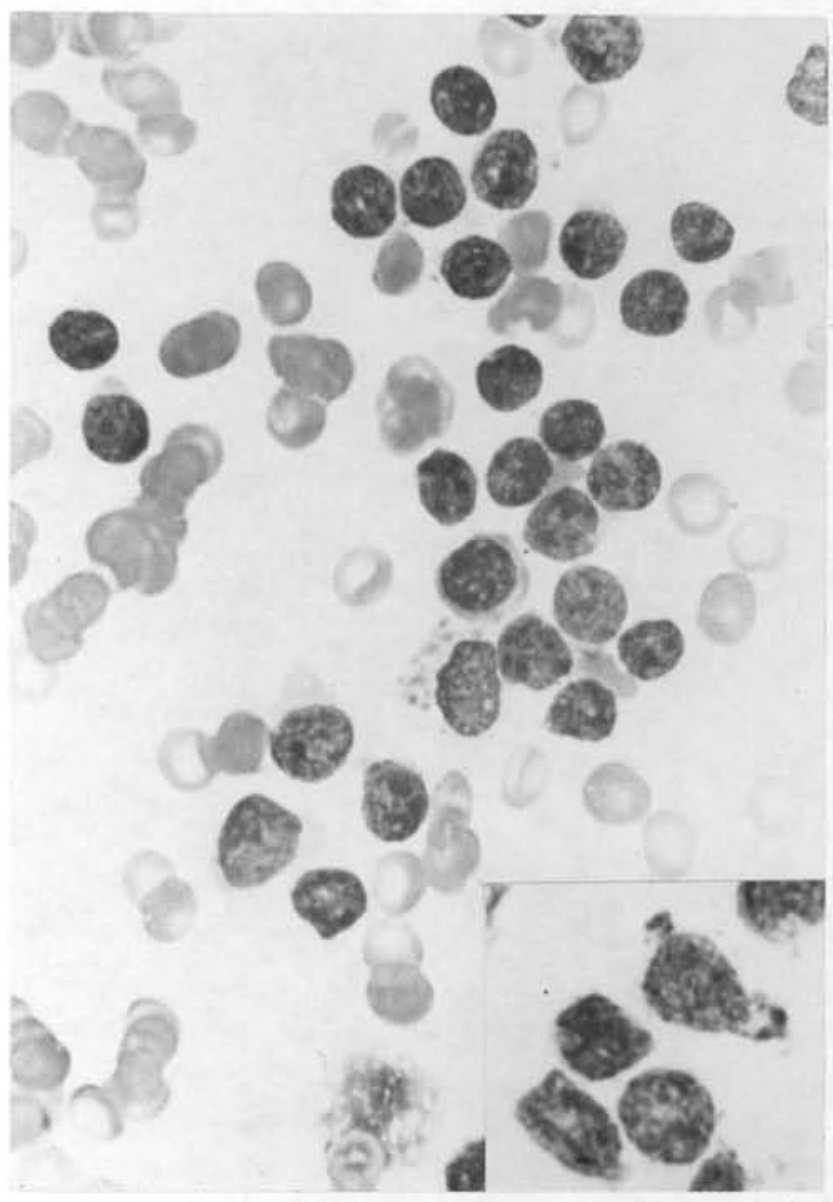

Figure 2 - Bone marrow smears at the time of lymphoblastic transformation of MDS. Pronounced infiltration of small blasts (Romanovsky, 1000x), some of which had PAS positive cytoplasmic granules (inset)

blast cells. Hemoglobin concentration was $4,5 \mathrm{~g} / \mathrm{L}$ and the platelet count was $100,0 \times 10^{9} / \mathrm{L}$. Bone marrow cytology showed an infiltration with small blast cells. Sudan black and chloroacetate esterase stains were negative in those blasts, while a PAS stain showed some granules in a small number of cells (Fig. 2). These findings were consistent with the diagnosis of acute lymphoblastic leukemia. Immunophenotypic analysis of the bone marrow aspirate by flow cytometry showed that leukemic cells were $C D$ 19 positive $(67 \%)$ and $\mathrm{SIg}, \mathrm{CD} 2, \mathrm{CD} 33$, and CD34 negative. Induction therapy for ALL with daunomycin, vincristin and prednisone ${ }^{27}$ resulted in complete remission. Dysplastic features were not conspicuous in erythroblasts, granulocytes or megakaryocytes, in bone marrow aspirate obtained after induction chemotherapy. The patient was then treated with intensification and maintenance chemotherapy for ALL. Two years later, pallor and splenomegaly returned. The leucocyte count was $2,0 \times 10^{9} /$ L with $40 \%$ neutrophils, $58 \%$ lymphocytes, and $2 \%$ monocytes. The hemoglobin concentration was $8,2 \mathrm{~g} / \mathrm{dL}$, 


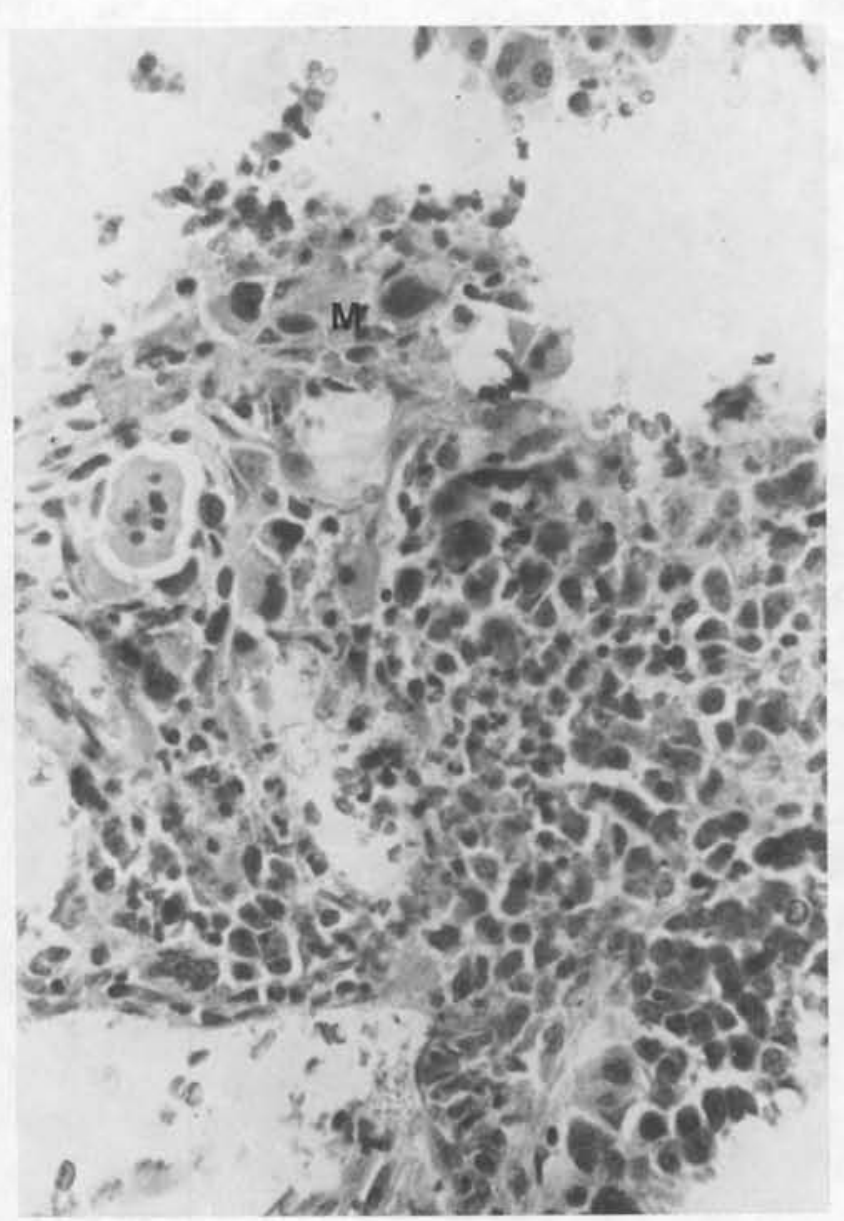

Figure 3 - Bone marrow biopsy two years later at the time of the onset of pancytopenia. Hematopoietic tissue was hypercellular, showing severe fibrosis and clusters of atypical megakaryocytes. An ALIP is seen at lower left (H.E., 600x)

and platelet count was $95,0 \times 10^{9} / \mathrm{L}$. The bone marrow biopsy findings showed the reappearance of MDS, now presenting pronounced fibrosis. Some groups of blast cells (ALIP) could be seen on bone marrow histological examination at this time (Fig. 3). Three months later, the patient was readmitted to hospital due to shortness of breath and fever. The leucocyte count was $5,8 \times 10^{9} / \mathrm{L}$ with $34 \%$ neutrophils, $12 \%$ lymphocytes, and $50 \%$ blast cells. The hemoglobin concentration was $7,6 \mathrm{~g} / \mathrm{dL}$, and the platelet count was $90,0 \times 10^{9} / \mathrm{L}$. Bone marrow aspirate findings showed $30 \%$ small blast cells with a small rim of cytoplasm, sometimes with blebs (Figure 4). Chloroacetate esterase stain revealed a focal positivity in the blast cells. No positivity was observed in Sudan black and PAS stains. Immunophenotypic analysis of peripheral blood by flow cytometry showed that leukemic cells were CD13 (40\%), CD61 (9\%) positive and CD2, CD3, CD10, CD19, CD33 negative. Bone marrow histological examination showed

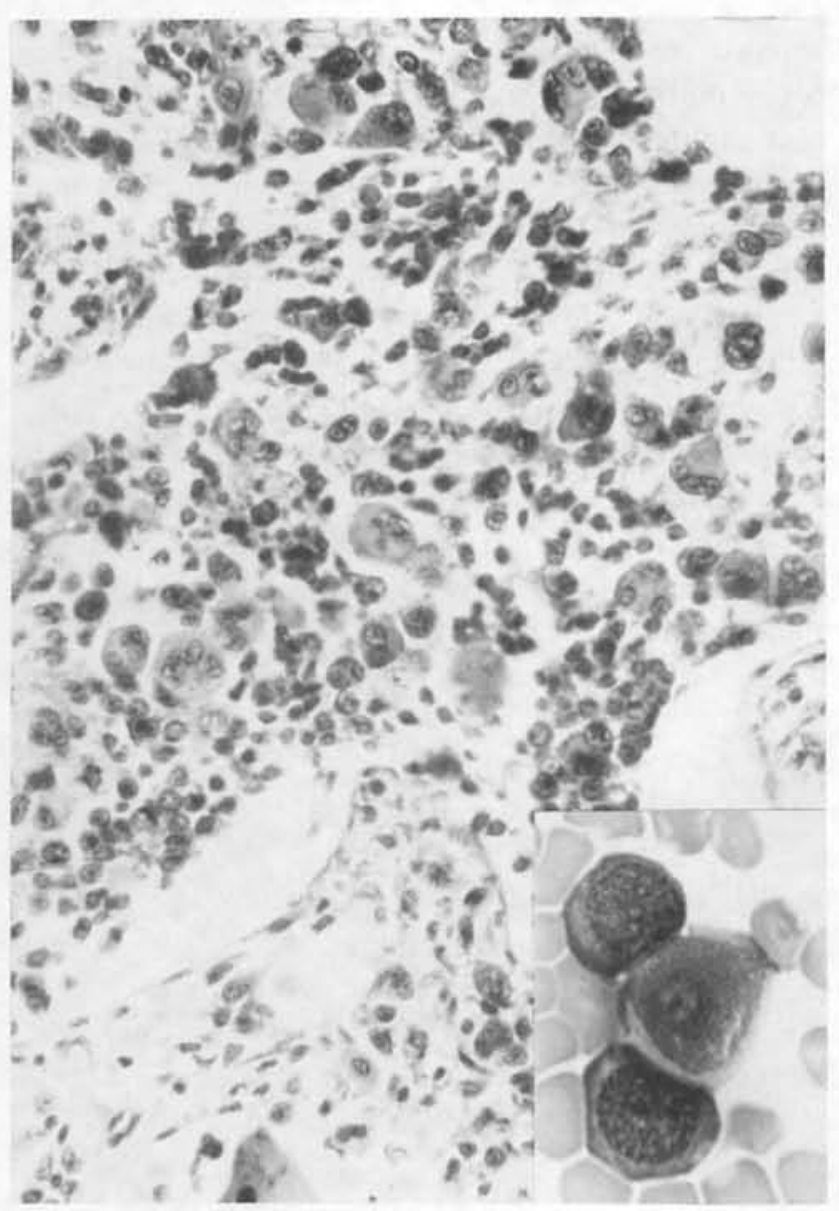

Figure 4- Bone marrow biopsy at the final megakaryoblastic transformation of MDS. Hypercellular marrow showing diffuse fibrosis, widened sinusoids and a proliferation mainly of blasts and atypical megakaryocytes (H.E., 600x). Inset: cytologic features (Romanovsky, 1000x)

a diffuse and homogeneous infiltration with blast cells, many atypical megakaryocytes, and fibrosis (Figure 4). Immunohistochemistry was performed using the avidinbiotin-peroxidase technique (29). Positivity was obtained using the antibody for factor VIII: von Willebrand factor (polyclonal, Dako), whereas UCHL-1 (CD45RO, Dako), L 26 (CD 20, Dako), and lysozyme (polyclonal, Dako) were negative. The results were consistent with acute megakaryoblastic leukemia. The patient died shortly afterwards from sepsis.

\section{DISCUSSION}

The present case shows some remarkable features in the course of MDS. At the beginning. neripheral blood 


\section{RESUMO}

As sindromes mielodisplásicas (SMD) são doenças clonais da célula progenitora do tecido hemotopoiético. Aproximadamente um terço dos casos evoluem para leucemia aguda, em geral de linhagem mielóide. Entretando, poucos casos de transformação para leucemia linfoblástica aguda (LLA) tem sido descritos. Os autores apresentam um caso de anemia refratária que transformou para LLA dois meses após o diagnóstico e que foi tratada, com sucesso, com quimioterapia convencional. Dois anos após, uma forma hiperfibrótica de SMD foi detectada que evoluiu, finalmente, para uma leucemia megacarioblástica aguda. 0 curso da SMD do caso presente apresenta evidências que a SMD pode envolver o precursor pluripotencial, presente na evoluçäo clonal e documentada por sucessivas mudanças nos achados clínicos e hematológicos.

and bone marrow findings led to the diagnosis of MDS, refractory anemia type, according to FAB criteria. ${ }^{26}$ Two months later, overt leukemia developed. The morphologic features of the blasts, their pattern of PAS positivity and their immunological characteristics were those of acute lymphoblastic leukemia (ALL). Conventional chemotherapy for ALL resulted in complete remission that lasted for 25 months. During this period the peripheral blood counts were normal, and no conspicuous atypias could be found in erythroblasts, granulocytes and megakaryocytes. Although the initial findings in this case pointed to the diagnosis of refractory anemia, which usually runs a benign course, the patient developed acute leukemia in a few months. The progression of MDS to ALL is also unusual. Only a few cases showing this evolution have been reported in the literature, and in most of them, refractory anemia with excess of blasts presented a transformation to ALL. ${ }^{2.7 .9 .10}$ In our case, it is possible that ALL may have been the renewed appearance of an etiologically unrelated malignancy, although this form of acute leukemia is far more common in children than in adults in their sixties. However, such an association of events is thought to be very rare. There is much evidence that MDS has its origin in a pluripotent stem cell, 5.16 .18 .20 25.28 producing a variety of abnormalities in the hematopoietic cell lineages and frequently terminating in an acute myeloblastic leukemia. Rarely, MDS may progress to ALL. ${ }^{2-12}$ This has been shown by clonal analysis ${ }^{16,18.20-25.28}$ as well as by the description of alterations in the lymphocytes and the occurrence of autoimmune phenomena in MDS. ${ }^{1.5}$ Therefore, in our case ALL could have been the blast transformation of a refractory anemia. After two years, pancytopenia and a progressive splenomegaly developed. Bone marrow histologic findings disclosed features of MDS, now characterized by severe fibrosis, increase of atypical megakaryocytes and the presence of ALIPs. These features may be interpreted as a new clonal evolution of the disorder. Cases of MDS characterized by trilineage dysplasia, with proliferation of atypical megakaryocytes and bone marrow fibrosis have been repeatedly described as a special form of MDS, frequently found after radio or chemotherapy, that has a high probability of transformation into AML and a poor prognosis. ${ }^{30-32}$ However, it is difficult to exclude the possibility that the chemotherapy regimen, successfully used in the treatment of ALL in this case, was responsible for this clonal evolution. Secondary MDS or acute leukemia have been described in $5 \%$ to $10 \%$ of patients treated successfully with radiotherapy or polychemotherapy for solid tumors or lymphomas. It is however more common in patients receiving high doses of alkylating agents or etoposide. ${ }^{33,34}$ Our patient received mostly antimetabolites and relatively small doses of antracyclins and cyclophosphamide.

\section{REFERENCES}

1. Hoelze D, Ganser A. Clinical course of myelodysplastic syndromes. In: Hematology Oncology Clinics of North America. edited by H. P. Koeffler. Philadelphia: W. B. Saunders Company 1992:607-618.

2. Ascensao JL, Kay NE, Wright JJ et al. Lymphoblastic transformation of myelodysplastic syndrome. Am J Hematol 1986;22:431-434.

3. Barton JC, Conrad ME, Parmley RT. Acute lymphoblastic leukemia in idiopathic refractory sideroblastic anemia: evidence for a common lymphoid and myeloid progenitor cell. Am J Hematol 1980;9:109-115. 
4. Berneman ZN, Van Bockstaele D, De Meyer P, et al. A myelodysplastic syndrome preceding acute lymphoblastic leukaemia. Br J Haematol 1985;60:353-354.

5. Hamblin T. Immunologic abnormalities in myelodysplastic syndromes. In Hematology Oncology Clinics of North America. edited by H. P. Koeffler. Philadelphia: W. B. Saunders Company 1992:571-586.

6. Hussein KK, Salem Z, Bottomley SS, Livingston RB. Acute leukemia in idiopathic sideroblastic anemia: response to combination chemotherapy. Blood 1982;59:652- 656.

7. Inoshita $\mathrm{T}$. Acute lymphoblastic leukaemia following myelodysplastic syndrome. Am J Clin Pathol 1985;84:233-238.

8. Kouides PA, Bennett JM. Transformation of chronic myelomonocytic leukemia to acute lymphoblastic leukemia: case report and review of the literature of lymphoblastic transformation of myelodysplastic syndrome. Am J Hematol 1995;49:157-162.

9. Nagler A, Brenner B, Tatarsky I. Secondary refractory anemia with excess of blasts in transformation terminating as acute lymphoblastic leukemia. Acta Haemat 1986;76:1654- 1655.

10. Pereira AM, Tavares de Castro J, Santos EG, Perloiro MC, Catovsky D. T lymphoblastic transformation of refractory anaemia with excess of blasts. Clin Lab Haematol 1985;7:89-95.

11. Ruiz-Arguelles GJ,Toquero-Franco JO. Evidencia del origen pre-mieloide de las anemias dishemopoyeticus: leucemia indiferenciado (tipo I de la classificacion FAB). Rev Invest Clin 1987; 39:241-244.

12. Stark AN, Scott CS, Bhatt B, Roberts B. Myelodysplastic syndrome coexisting with acute lymphoblastic leukaemia. J Clin Pathol 1986;39:728-730.

13. Bonati, A, Delia D, Starcich R. Progression of a myelodysplastic syndrome to pre-B acute lymphoblastic leukaemia with unusual phenotype. Br J Haematol1986; 64: 487-491.

14. Eridani S, Chan LC, Halil O, Pearson TC.- Acute biphenotypic leukaemia (myeloid and null-ALL type) supervening in a myelodysplastic syndrome. $\mathrm{Br} \mathrm{J}$ Haematol 1985; 61: 525- 529.

15. Komatsu N, Yoshida M, Eguchi M, et al. Simultaneous expression of lymphoid and myeloid phenotypes in acute leukemia arising from myelodysplastic syndrome. Am J Hematol 1988; 28:103-106.

16. Neame PB, Soamboonsrup P, Browman G, et al. Simultaneous or sequential expression of lymphoid and myeloid phenotypes in acute leukemia. Blood 1985; 65: 142-148.

17. San Miguel JF, González M, Del Cañizo MC, López Borrasca A. Myelodysplastic syndrome evolving to a mixed myeloidlymphoid leukaemia. Hematol Oncol 1986; 4:175-176.

18. San Miguel JF, Hernández JM, González-Sarmiento R, et al. Acute leukemia after a primary myelodysplastic syndrome: immunophenotypic, genotypic, and clinical characteristics. Blood 1991;78:768-774.

19. Serke S, Stein H, Anagnostopoulos I, et al. Acute leukaemia with B and T- lymphoid and myeloid characteristics in a patient with a myelodysplastic syndrome. $\mathrm{Br} \mathrm{J}$ Haematol 1989; 72: 110- 111 .

20. Culligan DJ, Cachia P, Whittaker J, Jacobs A, Padua RA. Clonal lymphocytes are detectable in only some cases of MDS. Br J Haematol 1992; 81:346-352.

21. Janssen JWG, Buschle M, Layton M, et al. Clonal analysis of myelodysplastic syndromes: evidence of multipotent stem cell origin. Blood 1989; 73:248- 254.

22. Lawrence HJ, Broudy VC, Magenis RE, et al. Cytogenetic evidence for involvement of B lymphocytes in acquired idiopathic sideroblastic anemias. Blood 1987; 70: 1003-1005.

23. Meckenstock G, Fonatsch C, Heyll A, et al. T-cell receptor $\mathrm{g} / \mathrm{d}$ expressing acute leukemia emerging from sideroblastic anemia: morphological, immunological, and cytogenetic features. Leuk Res 1992; 16: 379-384.

24. Raskind WH, Tirvmali N, Jacobson R, Singer J, Fialkow PJ. Evidence for a multistep pathogenesis of a myelodysplastic syndrome. Blood 1984; 63:131-134.

25. White NJ, Nacheva E, Asimakopoulos FA, Bloxham D, Paul B, Green AR. Deletion of chromosome $20 \mathrm{q}$ in myelodysplasia can occur in a multipotent precursor of both myeloid cells and B cells. Blood 1994; 83:2809-2816.

26. Bennett JM, Catovsky D, Flandrin G, Galton DAG, Gralnick HR, Sultan C. Proposals for the classification of myelodysplastic syndromes. Br J Haematol 1982; 51: 189-199.

27. Clarkson B, Ellis S, Litle C, et al. Acute lymphoblastic leukemia in adults. Semin Oncol 1985; 12:160-179.

28. Tefferi A, Thibodeau SN, Solberg Jr LA. Clonal studies in the myelodysplastic syndrome using $\mathrm{X}$-linked restriction fragment length polymorphisms. Blood 1990; 75: 1770-1773.

29. Hsu SM, Raine R, Fanger H. A comparative study of the peroxidase-antiperoxidase method and an avidin-biotin complex method for studying polypeptide hormones with radioimmunoassay antibodies. Am J Clin Pathol 1981; 75: 734-738.

30. Lambertenghi-Deliliers G, Orazi A, Luksch R, Annaloro C, Soligo D. Myelodysplastic syndrome with increased marrow fibrosis: a distintict clinico-pathological entity. Br J Haematol 1991; 78: 161- 166.

31. Maschek H, Georgii A, Kaloutsi V, et al. Myelofibrosis in primary myelodysplastic syndromes. Eur J Haematol 1992; 48: 208- 214.

32. Ohyashiki K, Ohyashiki JH, Iwabuchi A, Nakazawa S, Ebyhara Y. Clinical and cytogenetic characteristics of myelodysplastic syndromes developing myelofibrosis. Cancer 1991; 68: 178-1831.

33. Bhavnani M, Morris Jones PH, Testa NG. Children in long term remission after treatment for acute lymphoblastic leukaemia show persisting haemopoietic injury in clonal and long-term cultures. Br J Haematol 1988; 71: 37-41.

34. Genuardi M, Zollino M, Serra A, et al. Long-term cytogenetic effects of antineoplastic treatment in relation to secondary leukemia. Cancer Genet. Cytogenet 1988; 33:201-211. 